\section{Evaluation of the WaveOne Gold and One Shape New Generation in Reducing Enterococcus faecalis from Root Canal}

Raquel Esmeralda Guillén', Cleber Keiti Nabeshima', Hector CaballeroFlores ${ }^{1}$, Miguel Roig Cayón², Montse Mercadé ${ }^{3}$, Silvana Cai ${ }^{4}$, Manoel Eduardo de Lima Machado ${ }^{1}$
'Department of Restorative Dentistry, School of Dentistry, USP - Universidade de São Paulo, São Paulo, SP, Brazil ${ }^{2}$ Department of Restorative Dentistry, Universitat Internacional de Catalunya, Barcelona, CT, Spain ${ }^{3}$ Department of Dentistry, Universitat de Barcelona, Barcelona, CT, Spain ${ }^{4}$ Derpartment of Microbiology, Institute of Biological Science, USP - Universidade de São Paulo, São Paulo, SP, Brazil

Correspondence: Manoel Eduardo de Lima Machado, Av. Prof. Lineu Prestes, 2227, 05508-000 São Paulo, SP, Brasil. Tel: +55-11-99993-2993. e-mail: professormachado@hotmail.com
Key Words: endodontics, enterococcus faecalis, root canal instrumentation.

\section{Introduction}

The root canal preparation is performed through cleaning, shaping and disinfection, and studies have shown more than $90 \%$ of the bacterial removal from root canal is promoted by the mechanical action of the instruments (1-3). However, remaining bacteria may be into dentinal tubules, lateral canals, isthmus and irregularities, and to develop an apical periodontitis (4).

Among the microorganisms present in endodontic infections, Enterococcus faecalis has been target of many studies because of its resistant to conventional endodontic treatment $(5,6)$ and is frequently isolated from persistent endodontic infections (7).

Automated systems have been one of the most technological advances in endodontics in the recent decades, and the single-file systems are highlighted because of their simplicity and reduced working time (8). However, these systems can differ as to their movement: reciprocating or continuous rotation, exemplified by the WaveOne (Dentsply Maillefer, Ballaigues, VD, Switzerland) and One Shape (Micromega, Besançon, FR-I, Français) systems, respectively (2). The WaveOne system has a convex triangular cross-section at the two thirds nearest of the shank and a concave triangle at the tip, while the One Shape system has a modified triangle with symmetrical radius and three cutting angles from the tip of the instrument to 2 $\mathrm{mm}$ along its length, the middle of the instrument has a transitions to two cutting angles, and the region closest to the shank has a "S" cross-section with two cutting angles. Although their movements are different, it has been observed that the WaveOne and One Shape systems have similarity between them and to both multiple-file systems and manual technique regarding bacterial removal from infected root canals (2).

However, flexibility and resistance of the instruments have been sought by means of design modifications of the instrument or heat treatment of the nickel-titanium alloy $(9,10)$. Following this evolution, the WaveOne Gold (Dentsply Maillefer) was developed, a reciprocating singlefile system characterized by a new thermally treated nickel-titanium alloy named "Gold". The gold process is a post-manufacturing procedure in which the ground NiTi files are heat-treated and slowly cooled. This process results in a distinctive gold finish that improves its resistance and flexibility far in excess of its predecessor (11). It has a parallelogram-shaped cross-section with two cutting edges in contact with the canal wall, alternating with an off-centred cross-section where only one cutting edge is in contact with the canal wall. It is available in four sizes: small (tip size 20, .07 taper), primary (tip size $25, .07$ taper), medium (tip size $35, .06$ taper), and large (tip size $45, .05$ 
taper). The One Shape also had design modifications which resulted in the One Shape New Generation (Micromega), a continuous rotary single-file system made of conventional nickel-titanium alloy with variable cross-section along its active region: there are three cutting angles with asymmetrical radius from the tip of the instrument to $2 \mathrm{~mm}$ along its length, the middle of the instrument transitions to two cutting angles, and the region closest to the shank has two cutting angles. Furthermore, it has variable pitch and variable helix angles along the instrument. This file has only one version for preparation of root canal (tip size 25, .06 taper), but the other two files - One Shape Apical 1 (tip size $30, .06$ taper) and 2 (tip size 37, .06 taper) - are available for larger apical preparation after instrumentation.

Researches have shown that the instrument design can influence the root canal preparation and the bacterial removal $(3,12)$. By considering that there are no microbiological studies using WaveOne Gold and One Shape New Generation, the aim of this study was to evaluate the WaveOne Gold and One Shape New Generation systems regarding the bacterial removal from root canals infected with $E$. faecalis by comparing them to the conventional WaveOne and One Wave Shape systems. The null hypothesis $\vec{s}$ tested was that there are no differences in the bacterial reduction promoted by novel and conventional single-file systems.

\section{Material and Methods}

\section{Preparation of Samples}

The sample size was calculated by using the BioEstat 5.0 software (Manuel Ayres, Belém, PA, Brazil) and selecting the ANOVA test. From data obtained in a pilot study with 20 root canals, the mean and standard deviation were used, and the effect size was established (ie, 0.74 ). The alpha type error of 0.05 and a beta power of 0.80 were stipulated. A total of 12 samples per group were indicated as the ideal size required for noting significant differences. Then, after approval by Ethical Committee of the School of Dentistry of the University of São Paulo (CAAE 62729916.0.0000.0075), 56 distobuccal root canals of the upper molars without curvature were standardized to $12 \mathrm{~mm}$ and instrumented to a working length of $11 \mathrm{~mm}$ up to a size $15 \mathrm{~K}$-file (Dentsply Maillefer, Ballaigues) under irrigation with distilled water. Only round and narrow canals with the initial apical diameter no longer than a size $15 \mathrm{~K}$-file were included. Round cross-section was observed though radiographs in buccolingual and mesiodistal directions showing ratio 1:1 of the space corresponding to the root canal lumen at 5 $\mathrm{mm}$ from the apex (13).

All The root canals were filled with 17\% EDTA (Fórmula Et Ação, São Paulo, SP, Brazil) for 3 min to remove the smear layer and rinsed with $5 \mathrm{~mL}$ of distilled water. The apex was covered with composite resin (3M, Saint Paul, MN, USA), and the external root surface was sealed with epoxy resin (Araldite, Brascola, Joinvile, SC, Brazil). The specimens were fixed onto 24-well polystyrene microtiter plates by acrylic resin and sterilized by ethylene oxide (Acecil, Campinas, SP, Brazil).

\section{Contamination of Samples}

A suspension of $E$. faecalis (ATCC 29212) in tryptic soy broth (TSB; Difco, Le Pont-de-Claix, RA, France) was prepared and standardized to 4 on the McFarland scale. Forty-eight root canals were contaminated with the $E$. faecalis suspension by an insulin syringe. The plates were shaked (Fisher Vortex Genie 2; Fisher scientific, Bohemia, NY, USA) during 5 min to remove air pockets and to promote better bacterial penetration into dentinal tubules. The 8 remaining uncontaminated root canals were filled with TSB. The specimens were incubated at $37^{\circ} \mathrm{C}$ for 21 days. The root canal contents were replaced with fresh TSB every $48 \mathrm{~h}$.

After the incubation period, the root canals were filled with distilled water. Initial samples (S1) were collected using three sterilized size 15 paper points (Dentsply Maillefer), which were inserted into the root canals up to working length for 1 minute each. The points were stored in tubes containing $500 \mu \mathrm{L}$ of peptone water followed by agitation in vortex for 1 minute, then, 6-fold serial dilutions were prepared. Different dilutions were plated in triplicate on $\mathrm{m}$-Enteroccocus agar culture medium (Difco). The plates were incubated at $37^{\circ} \mathrm{C}$ for $48 \mathrm{~h}$, and the bacterial count was measured (in CFU mL-1).

\section{Instrumentation of Specimens}

The contaminated specimens were divided into four groups ( $n=12)$ : Group 1 was prepared using the WaveOne Gold Primary file (tip size 25, .07 taper; Dentsply Maillefer), and Group 2 was prepared using the WaveOne Primary file (tip size 25, .08 taper; Dentsply Maillefer), both groups used the motor in reciprocating motion (X-Smart Plus, Dentsply Maillerfer). Group 3 was prepared using the tip size 25, .06 taper One Shape New Generation file (Micromega), and group 4 was prepared using the tip size 25, .06 taper One Shape file (Micromega), both groups used motor in continuous rotation motion (Dentsply Maillefer) at 400 rpm and torque $2.5 \mathrm{~N} . \mathrm{cm}$.

The file was introduced into root canal using 3 in-andout motions, gently penetrating in apical direction. Then, the root canal was explored up to working length of 11 $\mathrm{mm}$ using a size $15 \mathrm{~K}$ file. This kinematics was performed until reaching full working length.

Irrigation during instrumentation was performed with a total of $10 \mathrm{~mL}$ of distilled water by using a syringe and a 29-gauge NaviTip (Ultradent Products, South Jordan, USA), 
which was taken up to $2 \mathrm{~mm}$ short of the working length through an in-and-out motion associated to aspiration (Neovoni, NRS Indústria, Barueri, SP, Brazil) for better flow. The irrigation was repeated with each time after withdrawing.

The negative control consisted of 2 uncontaminated specimens instrumented according to each group, totalizing 8 uncontaminated root canals instrumented.

\section{Data Collection After Instrumentation}

To determine the bacterial count (in CFU $\mathrm{mL}^{-1}$ ) immediately after instrumentation (S2), the root canal was filled with distilled water, and scraping using a size 25 Hedström file was performed. The file was sectioned below the handle and dropped into a tube containing 500 $\mu \mathrm{L}$ of peptone water. Three sterilized size 15 paper points were inserted into the root canal for 1 min each and were stored in the same tube as the file.

The root canals were filled with distilled water and were closed by using cotton. Then, the plate was closed and incubated at $37{ }^{\circ} \mathrm{C}$ for 7 days. A third collection was performed in the same manner as for S2 to determine the bacterial count at 7 days after instrumentation (S3).

\section{Statistical Analysis}

The bacterial counts were submitted to Lilliefors test for data normality that did not show normal distribution, then, Friedman test was used for intragroup analysis, and Kruskal-Wallis with Dunn's post-hoc test were used for intergroup analysis. The level of significance for all analysis was $p<0.05$.

\section{Results}

All systems significantly reduced the bacterial amount in the root canal at immediate and 7-day sampling periods $(p<0.05)$. However, bacterial number was increased at 7 days after shaping $(p<0.05)$.

The comparison between groups showed that WaveOne Gold and One Shape New Generation promoted higher bacterial reduction compared to the WaveOne and One Shape systems $(p<0.05)$, but no significant difference was found between WaveOne Gold and One Shape New Generation or between WaveOne and One Shape ( $>0.05)$.

The negative control proved the aseptic condition during the experiment by the absence of bacterial growth in uncontaminated samples.

Table 1 shows the CFU $\mathrm{ml}-1$ of $E$. faecalis before instrumentation, as well as bacterial reduction at immediate and 7 days after instrumentation.

\section{Discussion}

Novel instruments have been developed to facilitate and improve the cleaning and shaping of the root canal system. However, in view of the new characteristics, it is necessary to clarify the consequence of these modifications. This essay showed that the novel single-file systems produce better bacterial reduction than the conventional ones.

The present study used the distobuccal root canals of upper molars according to previous studies (1-3). These root canals can be easily standardized due to their similar anatomy, that is, no curvatures and diameters compatible to instrumentation with tip size 25 files. The importance to evaluate the tip size of this instrument is based on the current tendency towards single-file systems. Premolars have been used in several endodontics studies $(5,6,14)$, but it is necessary instruments with diameters larger than tip 25. Moreover, molar is a tooth which requires the greatest amount of endodontic treatment (15). However, it is important to mention that root canals with oval crosssections are more difficult to be cleaning and shaping (13), then they should also be evaluated in the future.

The plate culture method was used since it has been widely applied to analysis of the bacterial reduction $(1-3,5,6,14,16)$. Although molecular methods are more sensitive and can detect uncultivable bacteria $(17,18)$, a specific cultivable bacterium was used in the present study, and the sensibility was not necessary because all samples have positive bacterial growth. Furthermore, studies have demonstrated similar results regarding bacterial reduction between culture-dependent and molecular methods (19).

The results of this study demonstrated that all systems significantly decreased the bacterial amount at immediate and 7-day sampling periods, which is in accordance with the
Table 1. Median (in CFU mL $\mathrm{m}^{-1}$ ) of initial (S1), immediate (S2) and 7 days collection (S3) and percentage bacterial reduction

\begin{tabular}{lccccccc}
\hline Group & S1* & S2 $^{*}$ & S3* & S1-S2 & $\%$ & S1-S3 & $\%$ \\
\hline Wave One Gold $^{\mathrm{a}}$ & $2.42 \times 10^{7}$ & $4.70 \times 10^{5}$ & $1.33 \times 10^{6}$ & $2.36 \times 10^{7}$ & 98.1 & $2.28 \times 10^{7}$ & 94.5 \\
$\begin{array}{l}\text { One Shape New } \\
\text { Generation }\end{array}$ & $2.36 \times 10^{\mathrm{a}}$ & $4.50 \times 10^{5}$ & $1.44 \times 10^{6}$ & $2.28 \times 10^{7}$ & 98.1 & $2.20 \times 10^{7}$ & 93.9 \\
Wave One $^{\mathrm{b}}$ & $2.09 \times 10^{7}$ & $8.50 \times 10^{5}$ & $1.95 \times 10^{6}$ & $2.00 \times 10^{7}$ & 95.9 & $1.92 \times 10^{7}$ & 90.9 \\
One Shape $^{\mathrm{b}}$ & $2.10 \times 10^{7}$ & $7.02 \times 10^{5}$ & $1.95 \times 10^{6}$ & $2.03 \times 10^{7}$ & 96.7 & $1.90 \times 10^{7}$ & 90.8 \\
\hline
\end{tabular}

*Same superscript symbol means statistically significant difference. Friedman test $(p<0.05)$; ${ }^{a-b}$ Same superscript letter means no significant difference in both bacterial reductions. Kruskal-Wallis and Dunn test $(\mathrm{p}<0.05)$. 
literature $(1-3,6,16)$. This essay was conducted in vitro; then, the results cannot be directly extrapolated to the clinical condition. However, these findings are consistent with previous clinical studies using rotary systems $(18,20,21)$. No instrumentation was able to eliminate the microorganism completely. Studies have shown that all automated systems lead to noninstrumented root canal wall after preparation $(12,22)$, and it may be a possible explanation for remaining bacteria at immediate collection. Alves et al. (23) observed no correlation between the percentage of unprepared areas and the bacterial reduction on root canal, but the authors used sodium hypochlorite during the preparation. Distilled water was used as irrigant in this study because the mechanical action of the instruments can only be evaluated without the influence of any antimicrobial chemical substance.

The comparison between immediate and 7-day samplings showed significant bacterial growth. This fact confirms that $E$. faecalis is resistant to instrumentation $(1,3)$, thus demonstrating the importance of using intracanal medicament between the appointments $(21,24)$. Although Vera et al. (24) have shown that an intracanal medicament interappointment maximizes the bacterial reduction before filling, the present study does not allow affirm whether the treatment using these instruments can be performed in single or multiple sessions because the association with chemicals irrigants should be considered.

The comparison between groups showed that WaveOne Gold and One Shape New Generation promoted higher bacterial reduction than WaveOne and One Shape systems, and no significant difference was found between WaveOne Gold and One Shape New Generation or between WaveOne and One Shape. These results demonstrate that reciprocating and continuous rotary movements do not influence the bacterial reduction, as reported by previous studies $(1,2,16)$. The better performance of the novel systems can be explained by the design of the instruments. The parallelogram-shaped cross-section of the WaveOne Gold system shapes the root canal asymmetrically, with only two points of contact being present during the reciprocating rotation. In this way, the instrument has a larger scape of debris so that a great amount of dentine can be removed coronally. The dentine compacted onto the root canal walls could obstruct the dentinal tubules and this might impair the removal of bacteria from inside them. Similar results were found by Tewari et al. (14) and Machado et al. (3), who also observed a better performance of a parallelogram-shaped cross-section instrument compared to other systems. The One Shape New Generation shows also asymmetrical movement, and additionally it has a variable pitch and variable helix angle along the instrument, which could also result in greater removal of dentin debris and more bacterial reduction consequently. So, the results suggest design of the instrument resulting a larger scape of debris during instrumentation is an advantage of these new systems regarding bacterial reduction. However, it is important to emphasise that although these findings have shown statistical difference, it cannot state that such differences have clinical implications. According to Siqueira and Rôças (25) the manifestation of the periapical infection is dependent of the bacterial number and the host defenses, and the bacterial load necessary to induce or sustain disease is unknown. Therefore, clinical studies considering antimicrobial irrigants should be carried out to confirm these findings.

In view of the results, one can conclude that novel single-file systems - WaveOne Gold and One Shape New Generation - promote better bacterial removal than the conventional WaveOne and One Wave Shape systems.

\section{Acknowledgements}

The authors thank Acecil for ethylene oxide sterilization.

\section{Resumo}

A proposta deste estudo foi avaliar os sistemas WaveOne Gold e One Shape New Generation em relação à remoção bacteriana de canais infectados com Enterococcus faecalis, comparando-os com seus sistemas convencionais WaveOne e One Shape. Quarenta e oito canais disto vestibulares de molares superiores esterilizados em óxido de etileno foram contaminados com E. faecalis por 21 dias, e então acoleta bacteriana inicial foi feita com cone de papel e plaqueadas em $\mathrm{M}$-enterococcus agar. Os espécimes foram aleatoriamente divididos em quarto grupos de acordo com a instrumentação: WaveOne Gold, One Shape New Generation, WaveOne e One Shape. Após instrumentação, amostras foram coletadas utilizando limagem e cones de papel imediatamente e 7 dias após o preparo. A redução bacteriana foi calculada e então feita análise intra grupos com teste de Friedman, e entre grupos utilizando Kruskal-Wallis e teste de Dunn, todos a 5\% de significância. Todas as técnicas reduziram significantemente o número de bactérias do canal radicular $(\mathrm{p}<0.05)$. WaveOne Gold e One Shape New Generation promoveram maior redução bacteriana que WaveOne e One Shape $(p<0.05)$, mas nenhuma diferença significante foi encontrada entre WaveOne Gold e One Shape New Generation ou entre WaveOne e One Shape ( $p>0.05)$. Novos sistemas de lima-única promovem melhor remoção bacteriana que seus sistemas convencionais.

\section{References}

1. Machado ME, Nabeshima CK, Leonardo MF, Reis FA, Britto ML, Cai S. Influence of reciprocating single-file and rotary instrumentation on bacterial reduction on infected root canals. Int Endod J 2013;46:10831087.

2. Nabeshima CK, Caballero-Flores $\mathrm{H}$, Cai $\mathrm{S}$, Aranguren J, Borges Britto $\mathrm{ML}$, Machado ME. Bacterial removal promoted by 2 single-file systems: WaveOne and One Shape. J Endod 2014; 40:1995-1998.

3. Machado MEL, Nabeshima CK, Caballero-Flores $H$, Elmadjian-Filho $M$, Duarte $M A H$, Ordinola-Zapata $R$, et al. Instrument design may influence bacterial reduction during root canal preparation. Braz Dent J 2017;28:587-591.

4. Ricucci D, Siqueira JF Jr, Bate AL, Pitt Ford TR. Histologic investigation of root canal-treated teeth with apical periodontitis: a retrospective study from twenty-four patients. J Endod 2009;35:493-502.

5. Vivacqua-Gomes N, Gurgel-Filho ED, Gomes BPFA, Ferraz CCR, Zaia AA, Souza-Filho FJ. Recovery of Enterococcus faecalis after single or 
multiple-visit root canal treatments carried out in infected teeth ex vivo. Int Endod J 2005;38:697-704.

6. Basmaci F, Öztan MD, Kiyan M. Ex vivo evaluation of various instrumentation techniques and irrigants in reducing $E$. faecalis within root canals. Int Endod J 2013;46:823-830.

7. Tennert C, Fuhrmann M, Wittmer A, Karygianni L, Altenburger MJ, Pelz $\mathrm{K}$, et al. New bacterial composition in primary and persistent/secondary endodontic infections with respect to clinical and radiographic findings. J Endod 2014;40:670-677.

8. Bürklein S, Hinschitza K, Dammaschke T, Schäfer E. Shaping ability and cleaning effectiveness of two single-file systems in severely curved root canals of extracted teeth: Reciproc and WaveOne versus Mtwo and ProTaper. Int Endod J 2102;45:449-461.

9. Pereira ÉS, Viana AC, Buono VT, Peters OA, Bahia MG. Behavior of nickel-titanium instruments manufactured with different thermal treatments. J Endod 2015;41:67-71.

10. Uygun AD, Kol E, Topcu MK, Seckin F, Ersoy I, Tanriver M. Variations in cyclic fatigue resistance among ProTaper Gold, ProTaper Next and ProTaper Universal instruments at different levels. Int Endod J 2016;49:494-499.

11. Webber J. Shaping canals with confidence: WaveOne Gold single-file reciprocating system. Roots 2015;1:34-40.

12. Busquim S, Cunha RS, Freire L, Gavini G, Machado ME, Santos M. A micro-computed tomography evaluation of long-oval canal preparation using reciprocating or rotary systems. Int Endod J 2015;48:1001-1006.

13. De-Deus G, Barino B, Zamolyi RQ, Souza E, Fonseca A Jr, Fidel S, et al. Suboptimal debridement quality produced by the single-file F2 ProTaper technique in oval-shaped canals. J Endod 2010;36:18971900.

14. Tewari RK, Ali S, Mishra SK, Kumar A, Andrabi SM, Zoya A, et al. Mechanical reduction of the intracanal Enterococcus faecalis population by Hyflex CM, K3XF, ProTaper Next, and two manual instrument systems: an in vitro comparative study. J Investig Clin Dent 2016;7:168-173.

15. Kirkevang L-L, Vaeth $M$, Hörsted-Bindslev P, Bahrami G, Wenzel A. Risk factors for developing apical periodontitis in a general population. Int Endod J 2007;40:290-299.

16. Dagna A, Arciola CR, Visal L, Selan L, Colombo M, Bianchi S, et al. Antibacterial efficacy of conventional and single-use $\mathrm{Ni}$-Ti endodontic instruments: an in vitro microbiological evaluation. Int J Artif Organs 2012;35:826-831.

17. Siqueira JF Jr, Rôças IN. Exploiting molecular methods to explore endodontic infections: part 1 - current molecular technologies for microbiological diagnosis. J Endod 2005;31:411-423.

18. Rôças IN, Neves MAS, Provenzano JC, Siqueira JF Jr. Susceptibility of asyet-uncultivated and difficult-to-culture bacteria to chemomechanical procedures. J Endod 2014;40:33-37.

19. Alves FRF, Rôças IN, Almeida BM, Neves MAS, Zoffoli J, Siqueira JF Jr. Quantitative molecular and culture analyses of bacterial elimination in oval-shaped root canals by a single-file instrumentation technique. Int Endod J 2012;45:871-877.

20. Neves MA, Provenzano JC, Rôças IN, Siqueira JF Jr. Clinical antibacterial effectiveness of root canal preparation with reciprocating singleinstrument or continuously rotating multi-instrument systems. J Endod 2016;42:25-29.

21. Paiva SS, Siqueira JF Jr, Rôças IN, Carmo FL, Leite DC, Ferreira DC, et al. Clinical antimicrobial efficacy of NiTi rotary instrumentation with $\mathrm{NaOCl}$ irrigation, final rinse with chlorhexidine and interappointment medication: a molecular study. Int Endod J 2013;46:225-233.

22. Marceliano-Alves MF, Sousa-Neto MD, Fidel SR, Steier L, Robinson $J P$, Pécora JD, et al. Shaping ability of single-file reciprocating and heat-treated multifile rotary systems: a micro-CT study. Int Endod J 2015;48:1129-36.

23. Alves FR, Andrade-Junior CV, Marceliano-Alves MF, Pérez AR, Rôças IN, Versiani MA, et al. Adjunctive steps for disinfection of the mandibular molar root canal system: A correlative bacteriologic, micro-computed tomography, and cryopulverization approach. J Endod 2016;42:16671672.

24. Vera J, Siqueira JF Jr, Ricucci D, Loghin S, Fernández N, Flores B, et al. One- versus two-visit endodontic treatment of teeth with apical periodontitis: a histobacteriologic study. J Endod 2012;38:1040-1052.

25. Siqueira JF Jr, Rôças IN. Clinical implications and microbiology of bacterial persistence after treatment procedures. J Endod 2008;34:1291-1301.

Received September 25, 2017 Accepted March 1, 2018 